\title{
DEVELOPMENT OF A SCALE TO MEASURE UNIVERSITY TEACHERS' ASSESSMENT LITERACY IN OSUN STATE
}

\author{
Adediwura, Alaba Adeyemi ${ }^{1}$ Ajayi, Oyedokun Samuel ${ }^{2}$ \\ 1Department of Educational Foundations and Counselling, Faculty of Education, \\ Obafemi Awolowo University, Ile-Ife \\ 2Department of General Studies, School of Multidisciplinary Studies, \\ Bamidele Olumilua University of Education, Science and technology, Ikere Ekiti
}

Article DOI: https://doi.org/10.36713/epra6845

DOI No: 10.36713/epra6845

\begin{abstract}
The study developed a scale for measuring assessment literacy of university teachers and determined the validity and reliability of the scale. This is with a view of improving university teachers' assessment literacy. The study adopted the survey design. The population comprised all lecturers working in universities within Osun State. The sample consisted of 549 university teachers that were not in training position (lecturer II and above) from different disciplines selected using convenient sampling technique in all the eight accredited universities within Osun state. The study made use of three instruments namely; University Teachers Assessment Literacy Scale (UTALS), Teacher Self-Efficacy Scale (TSES) and Teacher Burnout Scale (TBS). The results showed that the 60-item UTALS was reduced to 43 items after the psychometric procedure of item retention and deletion were applied. Scree plot and eigen value methods showed that the final UTALS construct validity had seven factors of university teachers' assessment literacy that accounted for $86.46 \%$ of the total scale variance and it significantly converge and diverge with the Teacher Efficacy Scale ( $r=0.75)$ and Teacher Burnout Scale (0.52) respectively. The internal consistency reliability of the scale was 0.96 (Guttman), 0.90 (Cronbach), and 0.96 (Spearman). The study concluded that the university teacher's assessment literacy scale developed in this study had adequate psychometric characteristics and is suitable for measuring assessment literacy of university teachers in Osun State. It was therefore recommended that the University Teacher's Assessment Literacy Scale be adopted by institutions of higher learning for the assessment of new and old academic staff members' assessment competency in order to help in the improvement of assessment standard of the institutions.
\end{abstract}

\section{INTRODUCTION}

Assessment is considered to be an important integral component in any instructional context and educational setting. In any higher institution of learning, it is a major business and plays at least two key roles; first in ensuring institutional quality and accountability, and second, in improving student learning (Ewell, 2009). University lecturers' use of assessment affects the depth and quality of what students learn, their choice of learning strategies, how they manage their study time (Australian National Training Authority, 2002), and quite significantly, their 


\section{SJIF Impact Factor 2021: 8.013| ISI I.F.Value:1.241| Journal DOI: 10.36713/epra2016 ISSN: 2455-7838(Online) EPRA International Journal of Research and Development (IJRD) Volume: 6 | Issue: 5 | May 2021 \\ - Peer Reviewed Journal}

motivation to continue learning (Harlen and Crick, 2003). Thus, the importance of assessment cannot be overstated. In fact, according to Anderson (2004) and Hannafin, Hill, Oliver, and Glazer (2003), no factor influences a learning environment as much as assessment. It is thus assumed that every higher institution of learning is aiming for an assessment future that includes three active ingredients: (1) balanced assessment systems, or assessment systems that meet the information needs of all assessment users - not just those concerned with accountability; (2) quality assessments at all levels within such a system, all of which produce dependable information about student achievement; (3) productive assessment dynamics, reflecting a clear understanding of the emotional dynamics of the assessment experience from the learner's point of view. This is refer to as the concept of assessment for learning - that is, student involvement in the assessment process as a way to promote learning, not merely measure it.

The conduct of quality assessments require that a teacher carefully consider key features of assessment. Stiggins, (1993) opined that such features include; teacher clarity about the purpose of the assessment, teachers need to start with a clear and appropriate vision of the learning target, designing assessment that is adequate and appropriate for the context and giving feedback of the results to intended user in a timely and understandable way. Aside the mentioned four quality assessment keys is another related key feature that ensure classroom effective use of assessments in the classroom: student involvement in the process while they are learning. As it turns out, students are key data-based instructional decision makers too maybe the most important ones. They can contribute most productively to their own learning success when we share with them student-friendly versions of the learning targets from the beginning of the learning.

The Nigeria educational system calls for the accountability of higher education in promoting student learning. In this regard, universities are expected to give paramount importance to two key components in the structure of academic programmes. They are: (i) clear and measurable programme learning outcomes, and (ii) quality assessment that is well-aligned with the intended outcomes. The relationship between these two components is an intricate one where the provision of clear and measurable learning outcomes is expected to guide the use and practice of assessment among university lecturers. However, many universities in Nigeria do not provide the lecturers with a clear policy on assessment nor provide necessary training for lecturers on assessment practice, hence leaving them clueless as to the 'what'and the 'how' of student assessment. This evidence in Nigeria university lecturers' use of assessment that tends to be restricted to paper-and-pencil tests with quizzes and traditional formats (such as multiple choice, true-false and essay questions) being the most widely and frequently utilized methods. The use of alternative and authentic assessments (e.g. observations, demonstrations, portfolios,

e.tc.) was found to be uncommon among the lecturers. The adherence to traditional formats is known to be a long standing practice, and provides some indication as to what Nigerian university lecturers commonly understand to be student assessment. It also suggests that their assessment knowledge and practice have not improved much over the years thus the assessment literacy of Nigeria universities teachers come to question. In order for assessment to be effective, classroom teachers need to be assessment literateknowledgeable about the key concepts of testing and how they can inform the design of assessments and decisions surrounding their usage. Knowing more about assessment will not only help you to assess your students more effectively, but it will also provide you with a means of evaluating your own teaching and help you to produce tests that will actually motivate your students to learn.

Assessment literates mean the ability to detect the differences between sound and unsound assessment (Stiggins, 1995). He specified that assessment-literate educators should be able to know: (a) the content and learning outcome to be assessed; (b) the purpose of having assessment; (c) the best way to assess the students' skills and knowledge; (d) the development of quality instrument to assess students' performance; (e) the potential problems with the assessment; (f) the prevention of the problem; and $(\mathrm{g})$ the awareness of the potential negative consequences of poor, inaccurate assessment. According to the standards for teacher competence in the Educational Assessment of Students (American Federation of Teachers, National Council on Measurement in Education, National Education Association, 1990), there are seven standards for teacher competence in classroom assessment. Teachers should be skilled in:1.choosing assessment methods that are suitable for the learning outcomes to be assessed; developing assessment instrument that are suitable for the learning outcomes to be assessed; administering, scoring, and interpreting the assessment findings of both externally-produced and teacher- 


\section{SJIF Impact Factor 2021: 8.013| ISI I.F.Value:1.241| Journal DOI: 10.36713/epra2016 ISSN: 2455-7838(Online) EPRA International Journal of Research and Development (IJRD)

produced assessment; using assessment results perceptively when making decisions about students' learning, teachers' teaching, school development, program, or curriculum; developing the reliable and valid grading procedures; communicating and reporting efficiently the assessment results to students, parents, school administers, and other educators; and recognizing the illegal, unethical, inappropriate uses of assessment information and methods of assessment.

Assessment literacy can be defined as the solid and sound educational assessment knowledge and skills that is required by teachers in assessing students' mastery of learning outcome. Thus, it is one of the most important responsibilities of teachers in classroom teaching and learning (Volante \& Fazio, 2007). The effectiveness of teaching methods used in classroom is reflected by the quality of the assessments used. Therefore, the results gathered from classroom assessments should be reliable and valid. According to the research findings, the problems of lack of teachers' consensus on deciding the most beneficial and suitable assessment practices, limited assessment training, lack of assessment knowledge and skills may result in the teachers' variation in implementing the classroom assessment (Suah, 2012).

There has been a growth of expectations concerning Nigeria universities teachers' assessment knowledge and skills. Universities teachers were required to implement assessment professionally and creatively so as to align with the learning outcomes in the curriculum standards as a means of improving students' learning ability and performance and in turn provide the nation with high level man power that is required for the development of the country. A substantial part of university teachers' professional time is devoted to assessment-related activities. Optimal implementation of these activities requires strong knowledge and abilities in educational measurement. Teachers' knowledge and abilities in educational measurement have been equated to assessment literacy. It entails knowing what it is being assessed, why it is assessed, how best to assess it, how to make a representative sample of the assessment, what problems can occur within the assessment process, and how to prevent them from occurring. There is a concern on the adequacy of most university teachers' assessment literacy. However, the management of most Nigeria universities does not determine the assessment literacy level of their teachers at the point of entry into teaching profession and most often do not organize in-service training for them on fundamentals of educational assessment. Thus, assessment literacy of most university teachers may be considered to be feeble and the issue of inaccurate and invalid educational assessment was mainly due to the unacceptably low levels of assessment literacy. As a result, it has prevented the students from reaching their full potential. Furthermore, little or no study are carried out by university management on teachers' adherence to the fundamental principles of educational assessment as recommended by experts when assessing students' learning quality, not much empirical studies have been carried out to validate existing Western teacher assessment literacy inventory for use among Nigeria university teachers and there is no known published locally developed scale in Nigeria with which this important attribute of a university teachers activities could be measured. This study is therefore, developed and validated a University Teachers' Assessment Literacy Scale (UTLS) for the measurement of university teachers' assessment literacy.

\section{OBJECTIVES OF THE STUDY}

The major objective of this study is to develop a valid instrument that is capable of measuring university teachers' assessment literacy. The specific objectives of the study are to develop a University Teachers' Assessment Literacy Scale (UTALS) for measuring assessment literacy of university teachers;

1. develop a University Teachers' Assessment Literacy Scale (UTALS) for measuring assessment literacy of university teachers;

2. determine the validity of the UTALS;

3. estimate the reliability of the sale;

\section{RESEARCH QUESTIONS}

The following research questions were raised to achieve the objectives of the study.

1. What items would be adjudged to measure university teachers' assessment literacy

2. What is the construct validity of the developed UTALS?

3. What is the convergent validity of the UTALS?

4. What is the divergent validity of the UTALS?

5. What is the factor structure of the developed UTALS?

6. What is the reliability of UTALS?

\section{METHODOLOGY}

The design employed for the study is the descriptive survey design. This is because the researcher is only interested in developing valid and reliable instrument with which university lecturers' assessment literacy 


\section{SJIF Impact Factor 2021: 8.013| ISI I.F.Value:1.241| Journal DOI: 10.36713/epra2016 ISSN: 2455-7838(Online) EPRA International Journal of Research and Development (IJRD)

could be measured. The population for the study comprised all the 2,485 lecturers working in universities within Osun State Southwest of Nigeria. A total of $1640(66.0 \%)$ of the teachers work in the two government owned universities in Osun State while the remaining $845(34.0 \%)$ work with private owned universities in the State. The sample consisted of 549 university teachers that were not in training position (lecturer II and above) from different disciplines. The university teachers were selected from all the eight National University Commission accredited universities in Osun State using convenient sampling. The sample comprised 339 male and 210 female lecturers. The sample also comprised 275 university teachers that were below the rank of Senior Lecturer, 199 Senior Lecturers and 75 university teachers above the rank of Senior Lecturer. A total of 305 of the selected university teachers were from public universities while the remaining 295 were from private universities.

The study made use of one self-developed instrument namely; University Teachers Assessment Literacy Scale (UTALS) and two adopted instruments; Teacher Self-Efficacy scale (TSES) and Teacher Burnout Scale (TBS). The University Teachers' Assessment Literature Scale (UTALS), Teacher Self-Efficacy Scale (TSES) and the Teacher Burnout Scale (TBS) were administered simultaneously on the selected university lecturer by the researcher with the help of 6 trained research assistants.

\section{RESULTS}

Research Question 1: What items would be adjudged to measure university teachers' assessment literacy
To answer this question, the initial 60 items first version of University Teachers' assessment Literacy Scale (UTALS) (see Appendix I) was evaluated with the aim of determining their appropriateness for the scale. The correlation matrix was examined so as to ascertain the first quality, high inter-correlation of the items (DeVellis, 1991). The 60 items of the UTALS were Factor Analyzed. This method was chosen because the researcher was interested in understanding the underlying structure of a set of variables (Conway \& Huffcutt, 2003). In the study, initial factor analysis of the 60 items loaded on nine factors and 10 of the 60 items had factor loadings less than 0.32 (Worthington \& Whittaker, 2006) and/or loaded on more than one factor. The 10 items were then eliminated from further analyses to obtain a 50 item second version of VBS (See Appendix II). An investigation into the 50 items after a second round of factor analysis revealed that the 50 items loaded on seven factors with reliability estimate (Cronbach Alpha $=0.888)$, items mean (3.136) and inter-item correlation (0.155) with seven items that were not satisfactorily inter-correlated and that increased the reliability of the scale if they are deleted. The reduction of the second UTALS version was based on Govaerts and Gregoire(2008) item reduction criteria which stipulated that any item affected by the three or any two of the conditions below should be expunged.

i. Items with Low Item Mean (LIM) 3.136 or less.

ii. Items with Low Item total Correlation (LITC) of 0.155 and below.

iii. Items having a High Cronbach's Alpha if Item Deleted (HCAID) of 0.888 or more.

After applying the rules, the following items as contained in Table 1 were retained in the developed university teachers' assessment literacy scale.

Table 1: University Teachers' Assessment Literacy Scale (Third and Final Version)

\begin{tabular}{lll}
\hline $\begin{array}{l}\text { S/N } \\
\text { OLD }\end{array}$ & $\begin{array}{l}\text { S/N } \\
\text { NEW }\end{array}$ & \multicolumn{1}{c}{ Statement } \\
\hline 1 & 1 & $\begin{array}{l}\text { Application of what was learnt in class is best assessed using performance test } \\
\text { Accurate and consistence grading of students' knowledge dependds on developing a } \\
\text { scoring rubric after getting a feel for what students can do }\end{array}$ \\
3 & 2 & $\begin{array}{l}\text { General impression on a student performance in a standardized test is only acceptable if } \\
\text { the reliability of the test does not exceed 0.06 }\end{array}$ \\
4 & 4 & $\begin{array}{l}\text { Assigning students' grade is an appropriate use of standardized test result } \\
\text { Students' prior performance before assigning a final grade should be considered in } \\
\text { improving the validity of continuous assessment grading procedure }\end{array}$ \\
6 & 5 & $\begin{array}{l}\text { A student with 80th percentile in a test is said to have scored } 80 \% \text { of the test items } \\
\text { correctly } \\
\text { To appropriately use assessment information, scores from standardized test should be } \\
\text { used to determine teacher instructional effectiveness }\end{array}$ \\
7 & 7 &
\end{tabular}

(C) 2021 EPRA IJRD | Journal DOI: https://doi.org/10.36713/epra2016 |www.eprajournals.com |427| 


\begin{tabular}{|c|c|c|}
\hline 8 & 8 & $\begin{array}{l}\text { The choice of an assessment that covers single-step problem solving skills is the best for } \\
\text { assessing students' problem solving abilities }\end{array}$ \\
\hline 9 & 9 & $\begin{array}{l}\text { Portfolio assessment is the most suitable for accurate assessment of students' performance } \\
\text { in anticipation of how students will perform in an external exam }\end{array}$ \\
\hline 10 & 10 & $\begin{array}{l}\text { Receiving a percentile ran } 60 \text { in a nationwide assessment, will yield a student's that is } \\
\text { national average }\end{array}$ \\
\hline 11 & 11 & $\begin{array}{l}\text { The result of a test in which a student received a scaled score of } 196 \text { with cut off score of } \\
200 \text { and standard error equal } 6 \text { should be ignored }\end{array}$ \\
\hline 12 & 12 & $\begin{array}{l}\text { Student's achievement is best reflected when grades are based on daily homework and } \\
\text { chapter tests with point deducted for poor efforts }\end{array}$ \\
\hline 13 & 13 & $\begin{array}{l}\text { A student with scores } 60^{\text {th }} \text { and } 56^{\text {th }} \text { percentile in two different tests needs a remedial } \\
\text { course on the test in which } 56^{\text {th }} \text { percentile is scored }\end{array}$ \\
\hline 14 & 14 & $\begin{array}{l}\text { Teachers should encourage students to practice with items from an alternate form of a } \\
\text { high stake test to improve their performance }\end{array}$ \\
\hline 15 & 15 & Item analysis should be carried out on each item of a test to examine the validity coefficient \\
\hline 16 & 16 & $\begin{array}{l}\text { A student is believed to know } 85 \% \text { of the content covered in an instructional unit if in a } \\
\text { test scored using a } 100 \text {-percent scale he/she scored } 85\end{array}$ \\
\hline 17 & 17 & $\begin{array}{l}\text { Norm- and criterion-referenced information is used when a teacher adjust his/her } \\
\text { instruction based on pretest result }\end{array}$ \\
\hline 18 & 18 & Grades assigned based on a single test could be biased against some minority students \\
\hline 19 & 19 & $\begin{array}{l}\text { The use of traditional assessment is involved when teacher assigned grades based on } \\
\text { classroom observation }\end{array}$ \\
\hline 20 & 20 & It is unethical for a teacher to use previous grades to adjust current grades \\
\hline 21 & 21 & $\begin{array}{l}\text { Teachers should check for clarity of sentence construction when designing story-based } \\
\text { mathematics test }\end{array}$ \\
\hline 22 & 22 & $\begin{array}{l}\text { The primary purpose for conducting formative assessment that involve teacher quick } \\
\text { "check in" on students understanding is to identify cumulative knowledge }\end{array}$ \\
\hline 23 & 23 & Utilizing a holistic scoring method minimize teacher subjectivity in scoring \\
\hline 25 & 24 & A test item with difficulty value between 0.50 and 0.75 should be discarded \\
\hline 26 & 25 & Portfolio grading system is by teachers to detect students level of content mastery \\
\hline 27 & 26 & $\begin{array}{l}\text { Authentic assessment should be considered in testing application of what was learnt in the } \\
\text { class }\end{array}$ \\
\hline 29 & 27 & $\begin{array}{l}\text { When comparison group is comprised of grade level peers, the general impression on a } \\
\text { student's performance in a standardized test is acceptable }\end{array}$ \\
\hline 30 & 28 & Standardized test result can be used to plan instruction \\
\hline 33 & 29 & $\begin{array}{l}\text { Utilizing information from a variety of assessments when making decision about student } \\
\text { learning is an appropriate us of assessment information }\end{array}$ \\
\hline 34 & 30 & $\begin{array}{l}\text { Students' problem- solving abilities is assessed using an assessment that is consistent } \\
\text { with the content and skills they were taught }\end{array}$ \\
\hline 36 & 31 & $\begin{array}{l}\text { A student with a percentile rank of } 60 \text { on the problem-solving skills subset of a statewide } \\
\text { assessment score above average }\end{array}$ \\
\hline 40 & 32 & $\begin{array}{l}\text { In anticipation of an external assessment teachers should plan so that it focuses on } \\
\text { concepts and skills to be covered on the test }\end{array}$ \\
\hline 42 & 33 & $\begin{array}{l}\text { I a test scored using a } 100 \text {-percent correct scale, a score of } 85 \% \text { means answering } 85 \% \text { of } \\
\text { the items on the test correctly }\end{array}$ \\
\hline 44 & 34 & Decisions like grades should be based on more than one piece of information \\
\hline 50 & 35 & $\begin{array}{l}\text { To plan classroom instruction, teachers should do a quick "check in" on the students to get } \\
\text { an impression of their understanding }\end{array}$ \\
\hline 51 & 36 & $\begin{array}{l}\text { Grading all responses to essay question } 1 \text { before grading responses to essay questions } 2 \\
\text { remove inconsistency in scoring }\end{array}$ \\
\hline 52 & 37 & rovide an accurate picture of what studer \\
\hline
\end{tabular}




\section{SJIF Impact Factor 2021: 8.013| ISI I.F.Value:1.241| Journal DOI: 10.36713/epra2016 ISSN: 2455-7838(Online) EPRA International Journal of Research and Development (IJRD)

\begin{tabular}{|c|c|c|}
\hline & & really know, it is recommended that teachers clarify items that are confusing \\
\hline 53 & 38 & A diagnostic assessment is used to identify students specific difficulties \\
\hline 54 & 39 & A test item with a discrimination value equal to -0.50 should be discarded \\
\hline 55 & 40 & $\begin{array}{l}\text { A restricted-response essay items that is concerned with students' demonstrating level of } \\
\text { understanding of several specific criteria is best scored using analytic rubric }\end{array}$ \\
\hline 56 & 41 & $\begin{array}{l}\text { To enhance school improvement in standardized exam the teachers must ensure alignment } \\
\text { between instruction and what is measured on the test }\end{array}$ \\
\hline 57 & 42 & $\begin{array}{l}\text { Criterion-referenced grading systems reflect each student's respective level of content } \\
\text { mastery. }\end{array}$ \\
\hline 60 & 43 & $\begin{array}{l}\text { Raw scores are purely criterion-referenced and percentile ranks are merely one form of } \\
\text { norm-referenced scoring }\end{array}$ \\
\hline
\end{tabular}

Research Question 2: What is the construct validity of the developed UTALS?

To answer this question, the Kaiser or eigenvalues greater-than-one criterion (Kaiser, 1960) and scree test, which involves an examination of a plot of the eigenvalues for breaks or discontinuities was used to determine the construct validity. To do this the Spector (1992) Exploratory Factor Analysis (EFA) technique for studying the dimensionality of a scale was applied so as to explore the dimensionality of
UTALS with the aim of determining (a) the number of factors that best represent the items and (b) the interpretation of the factors.

From the initial eigenvalues as presented in Table 2, seven factors of university teachers assessment literacy emerged, which accounted for $86.457 \%$ of the total scale variance on the UTALS. The factor solution was in line with the initial assumption of the researcher (which was seven).

Table 2: Eigenvalues and total variance on the UTALS

\begin{tabular}{|c|c|c|c|}
\hline \multirow[t]{2}{*}{ Component } & \multicolumn{3}{|c|}{ Initial Eigenvalues } \\
\hline & Total & $\%$ of Variance & Cumulative \% \\
\hline 1 & 9.747 & 20.668 & 20.668 \\
\hline 2 & 8.174 & 17.010 & 37.678 \\
\hline 3 & 6.583 & 13.310 & 50.988 \\
\hline 4 & 6.362 & 12.796 & 62.784 \\
\hline 5 & 5.847 & 11.598 & 73.382 \\
\hline 6 & 3.868 & 8.996 & 81.378 \\
\hline 7 & 2.184 & 5.079 & 86.457 \\
\hline 8 & .199 & .463 & \\
\hline 9 & .032 & .073 & \\
\hline 10 & .003 & .007 & \\
\hline 11 & $3.553 \mathrm{E}-016$ & $8.262 \mathrm{E}-016$ & \\
\hline 12 & $3.237 \mathrm{E}-016$ & 7.527E-016 & \\
\hline 13 & $2.839 \mathrm{E}-016$ & $6.603 \mathrm{E}-016$ & \\
\hline 14 & $1.979 \mathrm{E}-016$ & $4.601 \mathrm{E}-016$ & \\
\hline 15 & 4.052E-017 & $9.422 \mathrm{E}-017$ & \\
\hline 16 & $2.192 \mathrm{E}-017$ & 5.097E-017 & \\
\hline 17 & $1.793 \mathrm{E}-017$ & $4.170 \mathrm{E}-017$ & \\
\hline 18 & $1.187 \mathrm{E}-017$ & $2.759 \mathrm{E}-017$ & \\
\hline 19 & $9.611 \mathrm{E}-018$ & $2.235 \mathrm{E}-017$ & \\
\hline 20 & $6.703 \mathrm{E}-018$ & 1.559E-017 & \\
\hline 21 & $6.475 \mathrm{E}-018$ & $1.506 \mathrm{E}-017$ & \\
\hline 22 & $4.906 \mathrm{E}-018$ & $1.141 \mathrm{E}-017$ & \\
\hline 23 & $2.360 \mathrm{E}-018$ & $5.488 \mathrm{E}-018$ & \\
\hline 24 & $1.156 \mathrm{E}-018$ & $2.687 \mathrm{E}-018$ & \\
\hline 25 & $-1.308 \mathrm{E}-033$ & $-3.043 \mathrm{E}-033$ & \\
\hline
\end{tabular}

(c) 2021 EPRA IJRD | Journal DOI: https://doi.org/10.36713/epra2016 |www.eprajournals.com |429 | 


\section{EPRA International Journal of Research and Development (IJRD)}

Volume: 6 | Issue: 5 | May 2021 - Peer Reviewed Journal

\begin{tabular}{cc}
\hline 26 & $-7.816 \mathrm{E}-033$ \\
27 & $-2.906 \mathrm{E}-019$ \\
28 & $-1.152 \mathrm{E}-018$ \\
29 & $-2.598 \mathrm{E}-018$ \\
30 & $-3.980 \mathrm{E}-018$ \\
31 & $-6.596 \mathrm{E}-018$ \\
32 & $-7.326 \mathrm{E}-018$ \\
33 & $-9.678 \mathrm{E}-018$ \\
34 & $-1.189 \mathrm{E}-017$ \\
35 & $-1.532 \mathrm{E}-017$ \\
36 & $-1.610 \mathrm{E}-017$ \\
37 & $-2.117 \mathrm{E}-017$ \\
38 & $-9.122 \mathrm{E}-017$ \\
39 & $-1.628 \mathrm{E}-016$ \\
40 & $-2.603 \mathrm{E}-016$ \\
41 & $-2.727 \mathrm{E}-016$ \\
42 & $-4.292 \mathrm{E}-016$ \\
43 & $-5.879 \mathrm{E}-016$ \\
\hline
\end{tabular}

The standardized factor loadings for the 43 items were statistically significant at $p<.05$. Thus, the standardized item loadings of the UTALS items showed that the instrument is valid. Scree plot was also
$-1.818 \mathrm{E}-032$
$-6.758 \mathrm{E}-019$
$-2.680 \mathrm{E}-018$
$-6.041 \mathrm{E}-018$
$-9.257 \mathrm{E}-018$
$-1.534 \mathrm{E}-017$
$-1.704 \mathrm{E}-017$
$-2.251 \mathrm{E}-017$
$-2.766 \mathrm{E}-017$
$-3.564 \mathrm{E}-017$
$-3.743 \mathrm{E}-017$
$-4.923 \mathrm{E}-017$
$-2.121 \mathrm{E}-016$
$-3.785 \mathrm{E}-016$
$-6.053 \mathrm{E}-016$
$-6.341 \mathrm{E}-016$
$-9.980 \mathrm{E}-016$ $-1.367 \mathrm{E}-015$

employed to further confirm the number of factors on which the UTALS items would load. The plot is as presented in Figure 1.

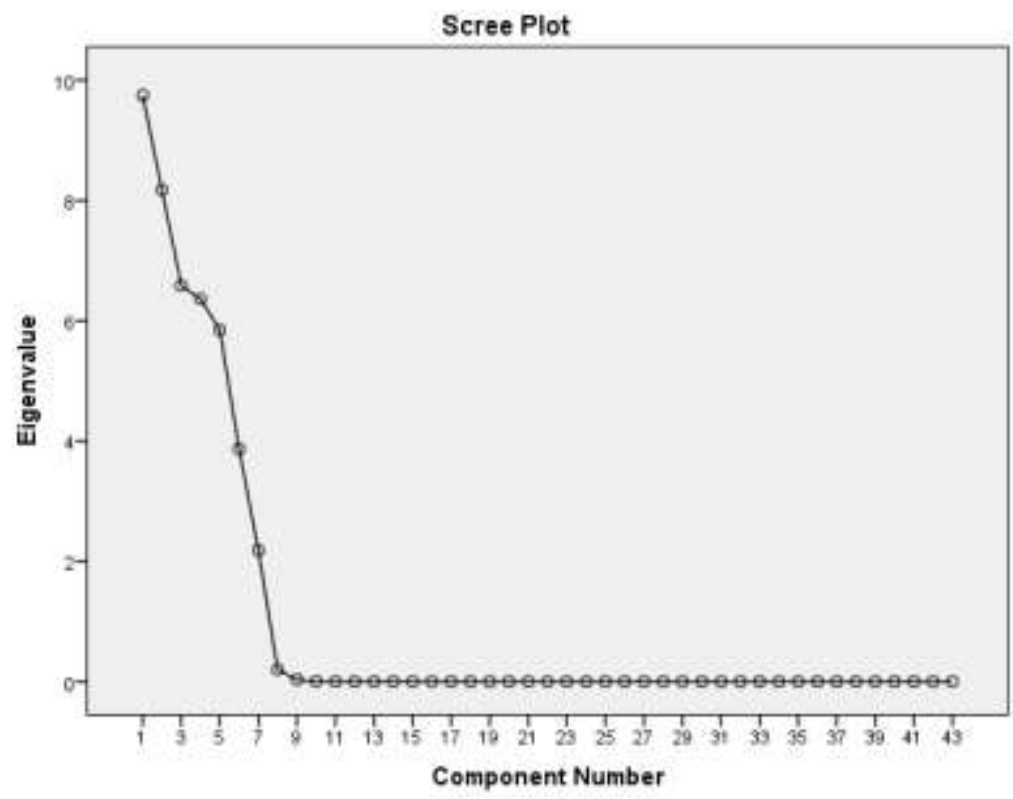

Figure 1: Scree plot showing seven factors on UTALS

The Scree plots in Figure 1 showed also seven factors Scale (UTALS) for measuring university teachers' on the UTALS and thus, confirm the number of factors assessment literacy. in Table 2. Thus, there are seven factors on the developed University Teachers' Assessment Literacy 


\section{SJIF Impact Factor 2021: 8.013| ISI I.F.Value:1.241| Journal DOI: 10.36713/epra2016 ISSN: 2455-7838(Online) EPRA International Journal of Research and Development (IJRD) \\ Volume: 6 | Issue: 5 | May 2021

Table 3: The UTALS third version subscales and corresponding items

\begin{tabular}{lll}
\hline S/N & \multicolumn{1}{c}{ SUBSCALE } & \multicolumn{1}{c}{ ITEMS } \\
\hline 1 & Developing Valid Grading Procedures & $5,12,18,23,26,44,51,57$ \\
2 & Using Assessment Results & $4,11,17,22,30,50,56$ \\
3 & Administering, Scoring and Interpreting the & $3,10,16,36,42,55$ \\
& & \\
& Results & \\
4 & Choosing Appropriate Assessment Methods & $1,8,27,29,34,53$ \\
5 & Developing Appropriate Assessment & $2,9,15,21,25,54$ \\
& Methods & $6,13,19,52,60$ \\
6 & Communicating Assessment Result & $7,14,20,33,40$, \\
7 & Recognizing Unethical and Otherwise & \\
& Inappropriate Assessment Methods & \\
\hline Eight of the 43 items of the UTALS loaded on & Methods). Thus, the 43 items on Table 1 were \\
1 (Developing Valid Grading Procedures). It & considered suitable and adequate to measure university \\
therefore be concluded that Developing Valid & teachers' assessment literacy
\end{tabular}

Grading Procedures is the most important of the factors. Seven items loaded on factor 2 (Using Assessment Results), which makes it next most crucial to the first factor on UTALS, Six items loaded on factor 4 and 5(Choosing Appropriate Assessment Methods and Developing Appropriate Assessment Methods) and five items loaded on each of factor 6 and 7 (Communicating Assessment Result and Recognizing Unethical and Otherwise Inappropriate Assessment

Research Question 3: What is the convergent validity of the UTALS?

To answer this question, scores from the Teacher Selfefficacy Scale (TSES)were correlated with those from the developed 43-item UTALS a related construct. Table 4 presents the result.

Table 4: Convergent validity of UTALS

\begin{tabular}{llllll}
\hline & $\mathrm{N}$ & $\overline{\mathrm{X}}$ & $\mathrm{SD}$ & $\mathrm{R}$ & $\mathrm{P}$ \\
\hline TSES & 551 & 33.56 & 4.77 & 0.747 & $<.01$ \\
UTALS & 545 & 131.72 & 12.67 & & \\
\hline
\end{tabular}

From Table 4, the correlation coefficient between the two scales, UTALS and TSES, was 0.477 , which is significant at 0.01 level of significance. Since the TSES is a widely used scale with a significant Cronbach's alpha that was found to be between 0.76 , and 0.82 using three samples for a period of one year and for a period of two years it was found to be .65 . A high and positive correlation with it by the UTALS thus establishes the validity of the latter. That is, the
UTALS does measure university teachers' assessment literacy in Osun State.

Research Question 4: What is the divergent validity of the UTALS?

To answer this question, scores from the Teacher Selfefficacy Scale (TSES) were correlated with those from the developed 43-item UTALS a related construct. Table 5 presents the result.

Table 5: Divergent validity of UTALS from Teacher Burnout Scale (TBS)

$\begin{array}{lllll}\mathrm{N} & \bar{x} & \mathrm{SD} & \mathrm{R} & \mathrm{P}\end{array}$

\begin{tabular}{llllll}
\hline TBS & 523 & 55.49 & 9.21 & -0.517 & $<.01$ \\
UTALS & 545 & 131.72 & 12.67 & & \\
\hline
\end{tabular}




\section{SJIF Impact Factor 2021: 8.013| ISI I.F.Value:1.241| Journal DOI: 10.36713/epra2016 ＩSSN: 2455-7838(Online) EPRA International Journal of Research and Development (IJRD)

From Table 5, the correlation coefficient between the two scales, UTALS and TBS, was -0.517 , which is significant at 0.01 level of significance. Since the TBS is a widely used scale with a significant subscales Cronbach's alpha of 0.89 for career satisfaction, 0.84 for perceived administrator support, 0.80 for coping with job related stress, and 0.72 for Attitudes towards students. A negative correlation with it by the UTALS thus establishes the divergent validity of the latter. That is, the UTALS does measure university teachers' assessment literacy in Osun State.

Research Question 5: What is the reliability of UTALS?

To answer this question, internal consistency reliability analyses were conducted on the 43 -items final version of University Teachers' Assessment Literacy Scale using SPSS (version 20). The results were as presented in Table 6.

Table 6: Internal consistency reliability estimates of the UTALS

\begin{tabular}{lll}
\hline Reliability Type & Coefficient & No of Items \\
\hline Cronbach Alpha & 0.901 & 43 \\
Spearman Brown (Split-half unequal Length) & 0.963 & 43 \\
Guttman Split-half Coefficient & 0.962 & 43 \\
Guttman & 0.909 & 43 \\
\hline
\end{tabular}

The results as presented in Table 6 showed that Cronbach Alpha coefficient of the UTALS was 0.901, while the Spearman Brown (split-half unequal length) coefficient was 0.963 and the Guttman coefficient was
0.909. These results are psychometrically satisfactory as opined by Devells (1991) cited by Adewolu (2006). Thus the UTALS can be considered reliable.

Table 7: University Teacher Assessment Literacy Scale Sub-scales Reliability

\begin{tabular}{lcc}
\hline \multicolumn{1}{c}{ Sub-scale } & $\begin{array}{c}\text { Cronbach } \\
\text { Alpha }\end{array}$ & No of Items \\
\hline Developing Valid Grading Procedures & 0.994 & 8 \\
Using Assessment Results & 0.899 & 7 \\
Administering, Scoring and Interpreting the Results & 0.914 & 6 \\
Choosing Appropriate Assessment Methods & 0.898 & 6 \\
Developing Appropriate Assessment Methods & 0.983 & 6 \\
Communicating Assessment Result & 0.918 & 5 \\
Recognizing Unethical and Otherwise Inappropriate & 0.973 & 5
\end{tabular}

Assessment Methods

The result as presented in Table 7 showed that UTALS sub-factors estimated reliabilities are very high, indicating that the items were internally consistent and can be used to measure university teacher assessment literacy consistently.

\section{DISCUSSION}

Arising from the difficulties in the adoption of Assessment Literacy Inventory in measuring university teachers' assessment literacy, this study developed and validated a university academic staff self-report assessment literacy measure. University Teachers' Assessment Literacy Scale (UTALS) was developed within the framework of Standards for Teacher Competence in Educational Assessment of Students, (AFT, NCME, \& NEA, 1990) and the current literature on teacher assessment literacy and practices. The $U T A L S$ was developed and analyzed within current frameworks of assessment. In this study the initial items generated for University Teachers' Assessment Literacy Scale (UTALS) were 85 items. These items were moderated and reviewed by experts in the fields of Tests and Measurement and Educational Psychology to determine the appropriateness, relevance and adequacy of the items (content validity). This was then reduced to 60 items. The 60 items were then subjected to psychometric properties analyses. The 60-item UTALS was reduced to 43-item final version based on Govaerts and Gregoire (2008) item reduction criteria. The validity of UTALS was examined through construct, convergent and divergent validity while the reliability was examined through internal consistency. A factor analytical technique, principal component analysis, was applied to determine the underlying component structure of the UTALS.

The principal component analysis results with eigenvalues greater-than-one showed that the 43 items that final emerged on the UTAL converge on seven 


\section{SJIF Impact Factor 2021: 8.013| ISI I.F.Value:1.241| Journal DOI: 10.36713/epra2016 ISSN: 2455-7838(Online) EPRA International Journal of Research and Development (IJRD) Volume: 6 | Issue: 5 | May 2021 \\ - Peer Reviewed Journal}

distinct components. The loading of the items on the components were moderate to high, and all loadings but one were above 0.5 . With the use of scree plot the seven factors on which UTALS loaded were confirmed. The seven factors are;Developing Valid Grading Procedures, Using Assessment Results, Administering, Scoring and Interpreting the Results, Choosing Appropriate Assessment Methods, Developing Appropriate Assessment Methods, Communicating Assessment Result and Recognizing Unethical and Otherwise Inappropriate Assessment Methods. All items were expected to correlate since the items were meant to represent the overall construct of university teachers' assessment literacy, the hypothesis that seven distinct components would emerge that lined up with each domain of assessment practices addressed in the UTALS was supported. This was in line with other studies that examine similar scales (Zhang, 1995; Burry-Stock \& Frazier, 2008). With UTALS 43-items correlating into distinct components, the results suggested that the scale as a whole is a strong measure of university teachers' assessment literacy and thus, it allows researchers to examine and discuss university teachers' assessment literacy as a unidimensional construct. The items on the UTALS showed evidence of construct validity as the initial factor loadings on the data collected using T-CARS were statistically significant. These were good enough for declaring the UTALS usable for measuring the invisible believe that university teachers assessment literacy is capable of enhancing (or impeding) the success with which teaching task would be discharged. The convergent and divergent validity of the UTALS were determined by examining the relationship between total score on the UTALS and total score on 10-items TSES and 20-items TBS respectively. A coefficient of 0.747 and -0.517 for showed that the UTALS correlates highly with the TSES and TBS respectively and has acceptable convergent and divergent validity.

The results of the examination of the psychometric properties of the STAP demonstrated internal consistency reliability. Cronbach's alpha, Guttman's and Split-half coefficients respectively were $0.901,0.909$ and 0.962 for all 43 items, which shows that the UTALS has good internal consistency as asserted by Adewolu, 2006.

\section{CONCLUSION}

The study therefore concluded that the developed 43-item UTALS, based on the analyses that were carried out could be adjudged reliable and valid for the measurement of university teachers' assessment literacy. It was therefore recommended that UTALS should be administered on university teachers upon their entry into the profession to ascertain their assessment literacy level and thus give insight on assessment competent skills training the teachers will require to be able to construct valid and reliable assessment tools.

\section{REFERENCES}

1. Adewolu, B. A. (2006). The development and validation of a teacher efficacy scale for Nigerian secondary school teachers. Unpublished Ph.D. Thesis, Faculty of Education, Obafemi Awolowo University, Ile-Ife, Nigeria

2. American Federation of Teachers, National Council on Measurement in Education, \& National Education Association. (1990). Standards for teacher competence in educational assessment of students. Washington, DC: National Council on Measurement in Education.

3. Anderson, T. (2004) Teaching in an online learning context, in Anderson, T.\&Elloumi, F. (eds.), Theory and practice of online learning. Canada: Athabasca University, 273-294.

4. Australian National Training Authority (ANTA). (2002)Assessment and online teaching: Australian flexible learning quick guide series. Available at: http://www.flexiblelearning.net.au/guides/assessme nt.pdf (Accessed: 8 February 2019).

5. Burry-Stock, J. A., \& Frazier, C. H. (2008, March). Revision of the assessment practice inventory (APIR): A combined exploratory factor analysis and polytomous IRT approach. Paper Presented at the American Educational Research Association, New York, NY.

6. Conway, J. M., \& Huffcutt, A. I. (2003). A review and evaluation of exploratory factor analysis practices in organizational research. Organizational Research Methods, 6, 147-168.

7. Cortina, J. M. (1993). What is coefficient alpha? An examination of theory and applications. Journal of applied psychology, 78(1), 98-104.

8. DeVellis, R. F. (2003). Scale development: theory and applications (2nd ed.). Newbury Park: Sage Publications

9. Ewell, P. T. (2009)Assessment, accountability, and improvement: revisiting the tension, NILOA Occasional Paper No.1, Urbana, IL: University of Illinois and Indiana University, National Institute for Learning Outcomes Assessment. Available at: http://www.learningoutcomeassessment.org/docum ents/PeterEwell_005.pdf

10. Govaerts, S.O. and Grregory J. (2008). Debt and Construct Validation of academic emotions scale. International Journal of testing 8(1), 34-54

11. Hannafin, M., Hill, J. R., Oliver, K., and Glazer, E. (2003) Cognitive and learning factors in webbased 


\section{EPRA International Journal of Research and Development (IJRD)}

Volume: 6 | Issue: 5 | May 2021
- Peer Reviewed Journal

distance learning environments,in: Moore, M. G. and Anderson, W. G. (Eds.)Handbook of distance education Mahwah, NJ: Lawrence ErlbaumAssociates.

12. Harlen, W., and Crick, R.D. (2003) Testing and motivation for learning,Assessment in Education, 10(2), 169-207.

13. Spector, P. E. (2006). Industrial and Organizational Psychology: research and Practice. $4^{\text {th }}$ edition. John Wiley \& Sons, New Jersey.

14. Stiggins, R. J. (1995). Assessment literacy for the 21st century. Phi Delta Kappan, 77.

15. Suah, S. L. (2012). Analisis model literasid anamal an pentaksiran guru sekolah sertaka jiantentan gjurangan tarakeduanya (Analysis of literacy model and assessment practices of school teachers and study of the culture gap) (Unpublished Ph.D. dissertation, School of Educational Studies, Universiti Sains Malaysia).

16. Volante, L. \& Fazio X. (2007). Exploring teacher candidates' assessment literacy: Implications for teacher education reform and professional development. Candian Journal of Education, 30(3), 749-770.

17. Zhang, Z. (1995). Investigating teachers perceived assessment practices and assessment competencies on the assessment practices inventory (API). The University of Alabama. ProQuest Dissertations and Theses, 163 p. http://search.proquest.com /docview/ 304160 100? accountid $=10639$. 